\title{
EVALUATION OF THE EFFECTS OF CLIMATE CHANGE ON RICE PRODUCTION IN NIGER STATE, NIGERIA \\ ${ }^{*}$ AYINDE O.E., ${ }^{1}$ OJEHOMON, V.E.T., ${ }^{2}$ DARAMOLA, F. S. ${ }^{1}$ and FALAKI, A.A. ${ }^{3}$ http://dx.doi.org/10.4314/ejesm.v6i6.7S
}

Received 18th July 2013; accepted 4th November 2013

\begin{abstract}
This study analyses the trend of climatic factors (rainfall, minimum and maximum temperature and humidity) in Niger state, Nigeria, as one of the major states contributing to the total rice output of the country. This study also describes the trend in rice production of Niger state and determined the factors affecting the output of rice in the state. Secondary data from 1981-2010 were used. The analytical tools used were descriptive analysis, unit root and co-integration. The result of the research reveals that there is variation in the trend of the climatic factors and also variation in rice output of Niger state. The finding also shows that humidity and minimum temperature are the climatic factors that affect the rice production of Niger state, such that $1 \%$ increase in humidity caused $17 \%$ reduction in rice production in Niger state while 1\% increase in minimum temperature caused $52.3 \%$ increase in rice production, therefore, humidity has a negative effect and minimum temperature has a positive effect. Therefore, the study recommends that research should be done to find the means of reducing the effect of climate change which will in turn improve the agricultural sector of the economy and rice production specifically. Also, breeders should help to develop rice varieties that can survive and produce well in adverse climatic conditions.
\end{abstract}

Key words: Effects, Climate Change, Rice Production, Niger State, Nigeria.

\section{Introduction}

Climate Change is a global crisis. It is estimated, by the inter-governmental panel on climate change, that there will be increase in global mean temperature of about $1^{\circ} \mathrm{C}$ above the present value by the year 2025 and $3^{\circ} \mathrm{C}$ before the end of next century (IPCC, 2002).

Some critical challenges that agriculture will face under climate changes are obvious. Many of which are the amplification of the substantial challenges that the current climate already imposes; water availability is at the top of the list. Water is already scarce in many regions, increasing demand and competition for water will combine with changing and less predictable rainfall and river flows (CGIAR, 2009). In Africa, where so many people rely directly on the rain for their foods and livelihoods, any changes

\footnotetext{
${ }^{I}$ Department of Agricultural Economics and Farm

Management, University of Ilorin, Nigeria

${ }^{2}$ National Cereals Research Institute, Badeggi, Niger State

Nigeria

${ }^{3}$ Department of Agricultural Extension and Rural

Development, University of Ilorin, Nigeria

*Corresponding author: opeayinde@yahoo.com
}

in rainfall present a major risk. Indeed the IPCC's fourth assessment report suggest that some African countries may see yields from rain fed agriculture fall by as much as $50 \%$ by 2020 , if production practices remain unchanged (IPCC 2007).

Schneider (1989) stated that water vapor and other "greenhouse gases" such as carbon dioxide, methane, and chlorofluorocarbons cause the greenhouse effect by trapping radiant heat emitted at infrared (long) wavelengths (as opposed to shorter, solar wavelengths which can pass through the atmospheric gases) from the earth's surface and reradiating it back to the earth's surface. This trapped energy effectively creates an enclosure around the earth's atmosphere similar to a greenhouse which not only traps heat, but also restricts air circulation that would otherwise cause cooling (Botkin and Keller 2000). Prior to the IPCC's report in 2001, there was still significant uncertainty about 
human beings' contribution to global warming. Many scientists believed that natural global cooling mechanisms worked to offset warming. With the release of the IPCC's Third Assessment Report in 2001, however, came new evidence that climate change over in the last 50 years was, indeed, attributable to humans, mostly from burning fossil fuels that emit more carbon dioxide into the atmosphere than it should contain to achieve climate equilibrium.

The variation in weather and climate has led to a lot of devastating consequences and effects in various parts of the country (Odjugo, 2010). These include flooding, deforestation, desertification, erosion, drought, sea level rise, heat stress, pests and diseases, erratic rainfall patterns, and land degradation. More specifically, the South-south geopolitical zone is mainly affected by sea level rise and deforestationinduced changes; South-East by erosion, flooding and land degradation: North-Central by changes due to de-vegetation and over-grazing; NorthEast by drought, desertification and heat stress, and North-West also by drought, desertification and heat stress (Ozor, 2009).

When temperature exceeds the optimal level for biological processes, crops often respond negatively with a steep drop in net growth and yield. Khanal (2009), stated that heat stress might affect the whole physiological development, maturation and finally reduces the yield of cultivated crop. The negative effect on agricultural yields will be exacerbated by more frequent weather event. high air temperatures reduce tillering, causes stunting (Futakuchi, 2005) and accelerate the developmental rate of rice thereby leading to shortened growing cycles. Thus higher temperatures induced by climate change may lead to substantial adverse effects on rice production. In a separate study, the simulated yield reduction from a $1{ }^{\circ} \mathrm{C}$ rise in the mean daily temperature varied from $5-7 \%$ for major crops, including rice (Matthews et al., 1997).

One of the most serious long-term challenges to achieve sustainable growth in rice production is Climate change (Wassmann et. al., 2007). Rice productivity and sustainability are threatened by biotic and abiotic stresses, and the effects of these stresses can be further aggravated by dramatic changes in global climate. Drought and flood already cause widespread rice yield losses across the globe and the expected increase in drought and flood occurrence due to climate change would further add to rice production losses in the future. Thus the major challenge is the potential adverse effect of changing climate on rice production and being the factor limiting increase in annual yield. Droughts can also affect irrigated rice fields with poor water control. Water stress has been identified as one of the most important production constraint in Africa. Crop failure due to drought generally occurs once every five years (Africa Rice Center, 2004).

Agriculture also had its effect on climate change just as climate change had on agriculture, According to Smith et al., (2008), agriculture sources such as animal husbandry/ manure management and agricultural soils account for about $52 \%$ of global nitrous oxide $\left(\mathrm{N}_{2} \mathrm{O}\right)$ emissions. In the past, deforestation and intensive agriculture (e.g, cultivating grasslands) have contributed significantly to the increase in atmosphere from agricultural activities than from fossil-fuel burning (Lal et al., 1998). Betts et al., (2007) demonstrated that historical deforestation of predominantly northern temperate regions, which their snow cover during winter, probably did not contribute to global warming, if the effect on temperature due to increase in land use change is taken into account. On present impact of agriculture on climate change, Boucher et al., (2004) examined the human influence of irrigation on atmospheric water vapor and climate. They estimated a global mean radioactive forcing in the range of 0.03 to $0.1 \mathrm{wm}^{-2}$ due to increase in water vapor in the atmosphere. There has been substantial progress in agriculture in recent years in reducing greenhouse gases - emission intensities, that is, emission per unit of product. For example over the last 20 years, a significant reduction in greenhouse gases emission intensities has been reported for the major livestock industries in Canada (Verge et al., 2009).

In effort to reduce the effect of climate change on major staple crops in Nigeria, various studies have been carried out but no major research has been done to look into the main climatic factors 
causing the annual reduction in overall agricultural production. It is already established that climate change is a continuous phenomenon and it is a major threat to development and food security for the coming decades, therefore findings need to be hasten up to find ways to reduce the adverse effect of these uncertain changes.

The main objective of this study is to determine the effect of climate change on rice production in Niger state and the specific objectives are to examine the trend of climate change in the study area from 1981-2010, describe the rice production trend in Niger and analyze the effect of climate change on rice production.

\section{Conceptual Framework}

The determination of climate - agriculture relationship can be done by studying agricultural data and climate variables data for a number of places within a given area, for as long a period as consistent records of both agriculture and climate allow, and deducing agro-climatological relationship from analysis of the data (Olaniyan, 1981). This paper assumes that data will not be tied to its historical mean. However, it is expected that data overtime will be tied together and will move up and down independent of the behaviour of each other. This results into the existence of co-integration. A presence of cointegration implies the existence of a long-term relationship between the endogenous and the exogenous variables (Ayinde et al 2013). The existence of co-integration can be handled by Error Correction Mechanism (ECM). The study employed the Error Correction Model (ECM) within the context of co-integration theory to analyze the data. The estimation procedure was used to overcome the problems of spurious correlation often associated with non-stationary time-series data. Further, the procedure is able to generate long-run relationships (Engle and Granger, 1987; Johansen and Juselius, 1990; Goodwin and Schroeder, 1991 Johansen, 1992). In using Error Correction Model (ECM), the first step is to assess the order of both the dependent and independent variables in the model. The order of integration ascertains the number of times a variable will be differentiated to become stationary. Dickey-Fuller statistics (DF) and Augmented Dickey-Fuller statistics (ADF) was used in this study to test the stationarity of individual series (Dickey and Fuller 1981).

\section{Methodology \\ Area of Study}

Niger State is located between Latitude $8^{\circ} 22^{\prime} \mathrm{N}$ and $11^{\circ} 30^{\prime} \mathrm{N}$ and Longitude $3^{\circ} 30^{\prime} \mathrm{N}$ and $7^{\circ} 20^{\prime} \mathrm{E}$ and covers a land area of about 74,244 sq.km, or about $8 \%$ of Nigeria's total land area. This makes the state the largest in the country. The State is bordered to the North by Zamfara State, to the Northwest by Kebbi State, to the south by Kogi State, to southwest by Kwara State; while Kaduna State and Federal Capital territory border the state to northeast and southeast respectively (see figure 1). The maximum temperature is recorded between March and June, while the minimum is usually between December and January. The rainy season lasts for about 150 days in the Northern parts of about 120 days in the Southern parts of the State. Generally, the climate soil and hydrology of the State permit the cultivation of most of Nigeria's staple crops and still allows sufficient opportunities for grazing, fresh water fishing and forestry development. 


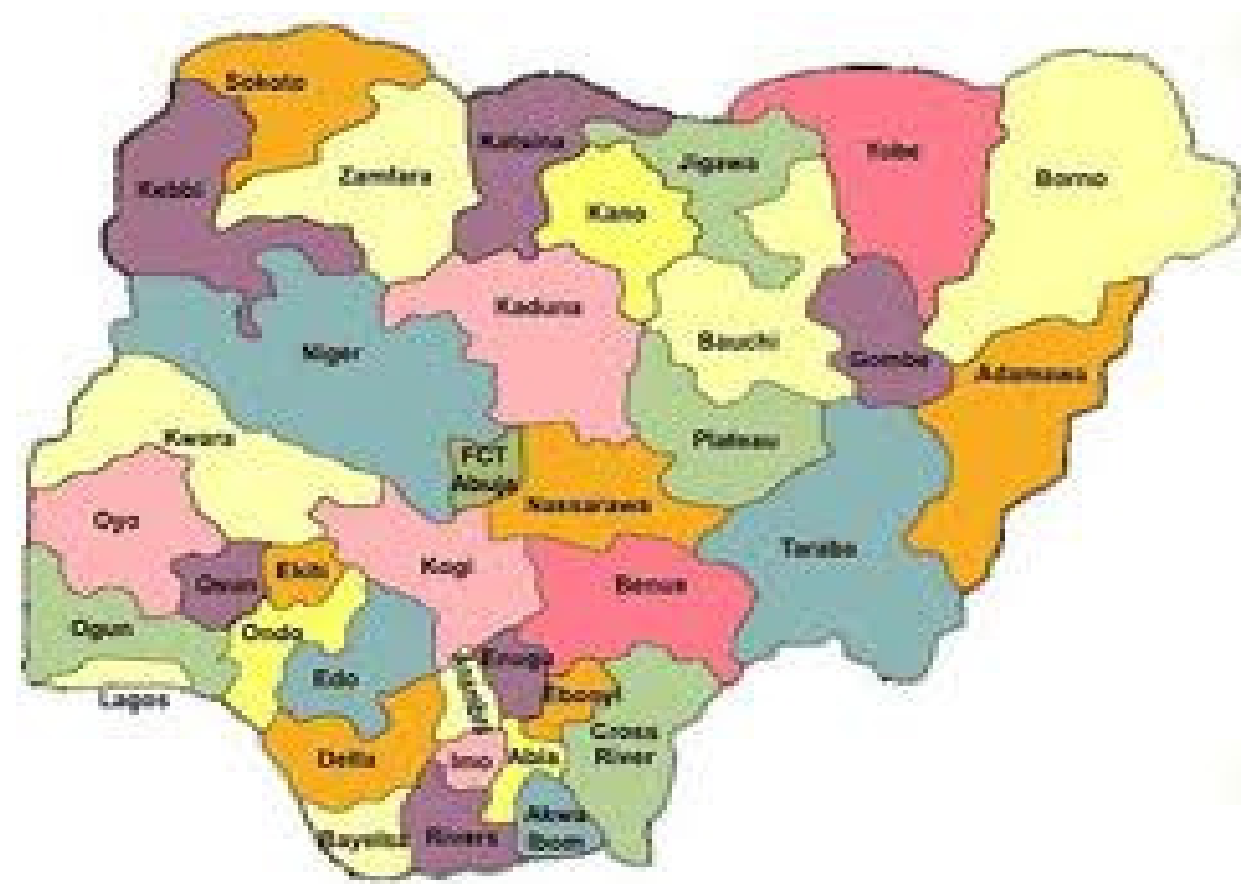

Figure 1 Map of Nigeria

\section{Data Collection and Analysis}

The set of data for this study were time series data from secondary sources. Secondary data from 1981-2010 were used. The data on climate was collected from National Cereal and Research Institute (NCRI) meteorological station and production data from Food and Agricultural Organisation, National Bureau of Statistics and Central bank of Nigeria.

Descriptive graph is used to show the trend of Climatic factors which are rainfall, minimum and maximum temperature and humidity. Also, the production trend (output) of Rice in Niger state was also described through the graph. Cointegration process integrates short-run dynamics with long run equilibra, this analysis first involves the test for unit root or stationary test. The Augmented Dickey-Fuller (ADF) test was used for this test. The ADF F-ratio critical value was used to make decision on the unit root of the variables. The Johansen procedure was used to test for co-integration in the model. Johansen technique was used not only because it is vector auto-regressive based but because it performs better in Multivariate model.

$$
\begin{aligned}
& L Y_{t}=\beta_{0}+\beta_{1} \mathrm{LX}_{1 \mathrm{t}}+\beta_{2} \mathrm{LX}_{2 \mathrm{t}}+\beta_{3} \mathrm{LX}_{3 \mathrm{t}}+\beta_{4} \mathrm{LX}_{4 \mathrm{t}}+\mathrm{U}_{\mathrm{t}} \\
& \text { Where } \mathrm{Yt}=\text { annual rice output }(\mathrm{kg}) \\
& \mathrm{X}_{1}=\text { annual average rainfall }(\mathrm{mm}) \\
& \mathrm{X}_{2}=\text { annual average minimum } \\
& \text { temperature }\left({ }^{0} \mathrm{C}\right) \\
& \mathrm{X}_{3}=\text { annual average maximum } \\
& \text { temperature }\left({ }^{0} \mathrm{C}\right) \\
& \mathrm{X}_{4}=\text { annual average humidity (mmHg) } \\
& \mathrm{t}=\text { years } \\
& \mathrm{U}_{\mathrm{t}=\text { error term }}
\end{aligned}
$$

\section{Results and Discussion}

Rainfall is one of the climatic factors affecting rice production; figure 1 shows the trend of rainfall in Niger state from 1981 to 2010. 


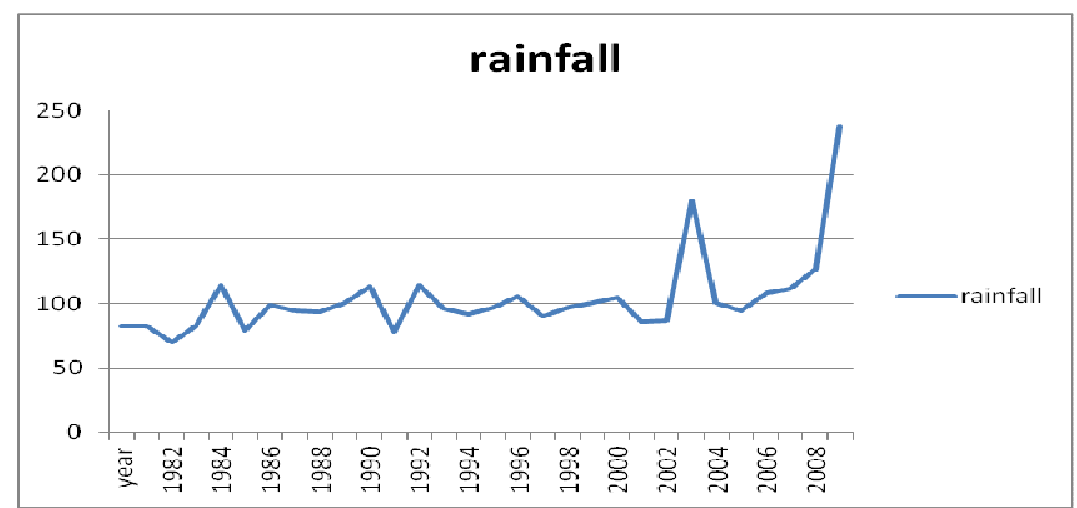

Figure 2 Graphical Representation of Rainfall Trend

Figure 2 shows that the rainfall is at its lowest in Niger state the year 1982. There was an increase in the amount of rainfall in 1984. Rainfall falls below $150 \mathrm{~cm}$ from the year 1981 to 2002. From this, it can be deduced that Niger state experience drought throughout those years. In the year 2002 to 2003 , there was a sudden increase in rainfall even above $150 \mathrm{~cm}$; this would surely lead to flood in Niger state. The rainfall amount falls back again to its original level in year 2004, maintaining the level it has being before i.e below $100 \mathrm{~cm}$. From the year 2005 to 2009 , the amount of rainfall has being on a continuous increase even above the $230 \mathrm{~cm}$ signifying another flood experience in the state.

\section{Maximum and Minimum Temperature}

The minimum and the maximum temperature measured in ${ }^{0} \mathrm{C}$ were other climatic factors took into consideration. The trends of the maximum and minimum temperature in Niger state from 1981 to 2010 are shown in figures 3 and 4 respectively.

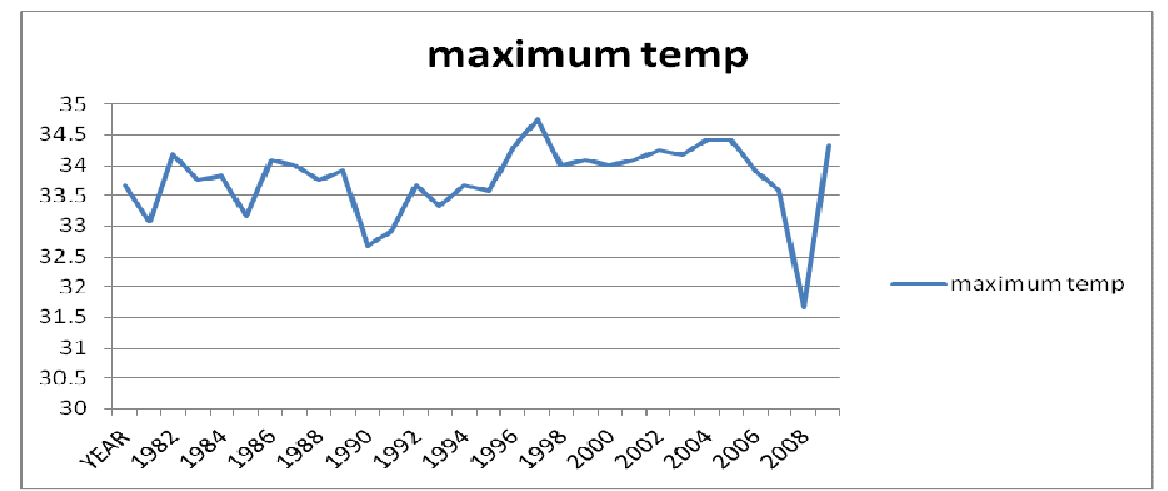

Figure 3 Graphical Representation of Trend of Maximum Temperature

\section{Maximum Temperature}

Figure (3) represents a graphical representation of maximum temperature in Niger state from the year 1981 to 2010 . The maximum temperature reached its highest in the year 1998 at 34.75 , this value confirms the decrease in amount of rainfall recorded also in the same year. This increase may be as a result of increase solar radiation, decrease in humidity and decrease in rainfall; the lower the rainfall, the higher the increase in temperature. The state also recorded decrease in maximum temperature in the years 1991,1992 and 2009 at $32.7^{\circ} \mathrm{C}, 32.9^{\circ} \mathrm{C}$ and $31.7^{\circ} \mathrm{C}$ respectively with 2009 being the lowest maximum temperature experienced. Increase in maximum temperature was recorded in the following year 2010, but never reach the highest one recorded in 1998. 
Minimum Temperature

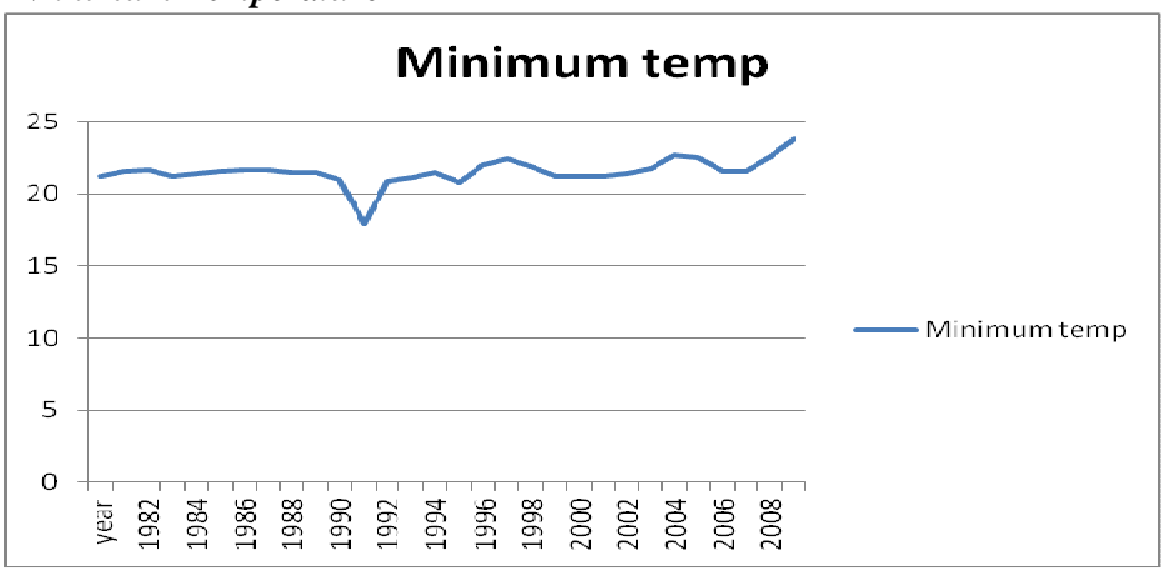

Figure 4 Graphical Representation of Minimum Temperature Trend

Figure (4) shows the trend of minimum temperature in Niger state from 1981 to 2010. Base on the graph, the minimum temperature values recorded from the year 1981 to 1990 were all a little bit above $21^{\circ} \mathrm{Cand}$ dropped to exactly $21^{\circ} \mathrm{C}$ in the year 1991 . There was a sudden shock in the minimum temperature in the year 1992, representing 19\% decrease in the minimum temperature. This shock may be likened to unsteady weather condition in the state. The minimum temperature went back to the position it was maintaining between $21^{\circ} \mathrm{C}$ and $22^{\circ} \mathrm{C}$, this shows a steady minimum temperature for Niger state.

The highest minimum temperature was recorded in the year 2010 at $23.8^{\circ} \mathrm{C}$. In conclusion, the minimum temperature ranged from $21^{\circ} \mathrm{C}$ to $23.8^{\circ} \mathrm{C}$ throughout the years under study.

\section{Relative Humidity}

The relative humidity represents the amount of water vapor in the atmosphere in a particular area. The effect of relative humidity on the growth of a particular crop cannot be over looked. Figure (5) represents the trend in relative humidity of Niger state, the graph showed that there is no stable pattern of humidity experienced in Niger state. There were upsurge in the relative humidity in years 1986, 1990 and 1991 reaching $775 \mathrm{mmHg}, \quad 774 \mathrm{mmHg}$ and $810 \mathrm{mmHg}$ respectively, this increase can be likened to increase rainfall and decrease in temperature in those years. Also, the relative humidity also reached its lowest values in the years 1983, 1997 and 1998; reason might also be increase in temperature and decrease in rainfall in those years

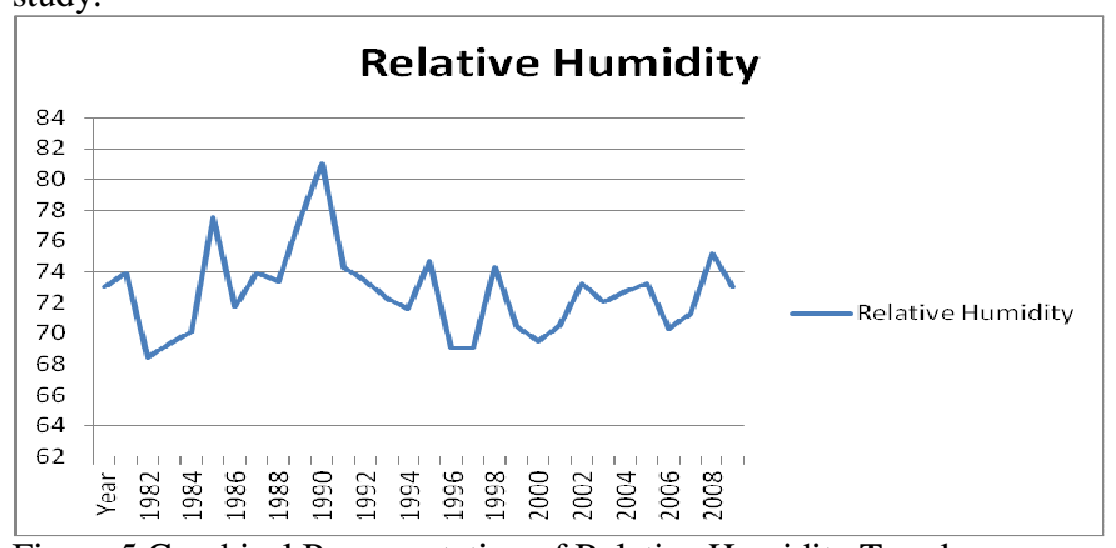

Figure 5 Graphical Representation of Relative Humidity Trend 


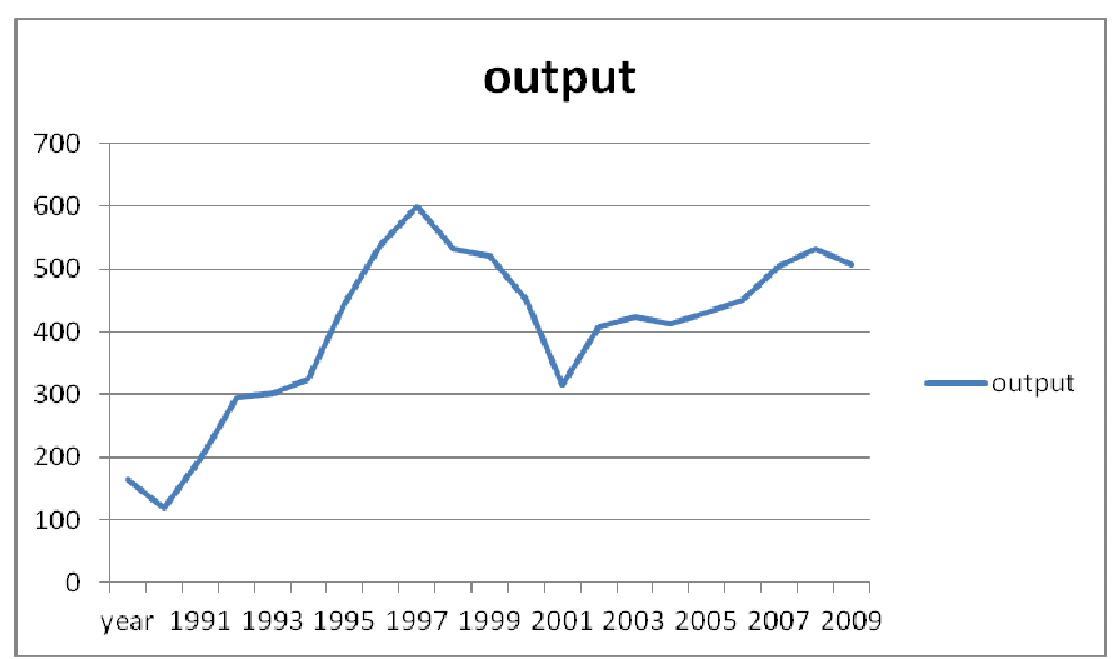

Figure 6 Graphical Representation of Trend of Rice Ouput

Niger state is one of the major contributions to rice production in Nigeria. Therefore the rice output trend was looked at to know the factors responsible for upsurge and shock in the trend.

From figure 6, there is an increase in the rice output from 1991 to 1998 , this increase can generally be linked to the policy initiated in the year 1985, when the federal government placed ban on importation of rice and maize into the country. In the year 1995, the federal government introduced $100 \%$ tariff on rice, this caused another shock in the total output. Looking at the graph, this tariff also affected Niger state output. These could have encouraged the rice farmers in Niger State to produce more to add to the country's total rice output. The highest rice production in Niger state was recorded in 1998 as 600960 tonnes representing $11.52 \%$ increase. This could be as a result of adoption of improved technology, favorable climate because the maximum temperature also reached its maximum in 1998. The rice output fall in the next year to 532870 tonnes representing $11.3 \%$ decrease; this decrease in output continued till 2002 at 315190 tonnes, showing a drastic reduction in the Niger state's rice output. The production again took a positive step forward when the rice output rise to 407200 tonnes and this gradual increase continued until 2009 reaching 532010 tonnes and didn't reach the former peak in 1997. The production took a step back in 2010 when it dropped to 506460 tonnes representing $4.85 \%$ decrease which may be due to increase in rice importation in the year and unavailability of financial help to the rice farmers.

The results of Climatic factors affecting rice production in Niger state are shown in tables 1-3. Stationary test, Johansen Co-integration and regression analysis were carried out to determine these factors.

Table 1 present the result of the Augmented Dickey-Fuller Test. Humidity is stationary at $1 \%$ at level while the Output is also stationary at $10 \%$ also at level. The other variables are not stationary at level but became stationary after first differencing. 
Table 1 Result of Stationary (Unit root) test

\begin{tabular}{|c|c|c|c|c|}
\hline Varibles & ADF-Statistics & Critical level & Order of integration & \\
\hline \multirow[t]{3}{*}{ Humidity } & & $1 \%=-3.831511$ & \multicolumn{2}{|l|}{ Stationary at level } \\
\hline & -4.610790 & $5 \%=-3.029970$ & & \\
\hline & $(0.0020)$ & $10 \%=-2.655194$ & & \\
\hline Maximum & -5.695594 & $1 \%=-3.831511$ & Stationary & First \\
\hline \multirow[t]{2}{*}{ Temperature } & $(0.0002)$ & $5 \%=-3.029970$ & difference & \\
\hline & & $10 \%=-2.655194$ & & \\
\hline Minimum & -3.211425 & $1 \%=-3.959148$ & Stationary & First \\
\hline \multirow[t]{2}{*}{ Temperature } & $(0.0396)$ & $5 \%=-3.081002$ & difference & \\
\hline & & $10 \%=-2.681330$ & & \\
\hline \multirow[t]{3}{*}{ Rainfall } & -4.610790 & $1 \%=-3.959148$ & Stationary & first \\
\hline & $(0.0296)$ & $5 \%=-3.081002$ & difference & \\
\hline & & $10 \%=-2.681330$ & & \\
\hline \multirow[t]{3}{*}{ Output } & -2.937042 & $1 \%=-3.959148$ & Stationary at level & \\
\hline & $(0.0596)$ & $5 \%=-3.081002$ & & \\
\hline & & $10 \%=-2.681330$ & & \\
\hline
\end{tabular}

Table 2 Co-integration results for rice production Unrestricted Cointegration Rank Test (Trace)

\begin{tabular}{lcllc}
\hline $\begin{array}{l}\text { Hypothesized } \\
\text { No. of CE(s) }\end{array}$ & Eigenvalue & Trace & 0.05 & \\
\hline None $*$ & 0.951825 & 87.60933 & 47.85613 & 0.0000 \\
At most 1 * & 0.739216 & 33.01668 & 29.79707 & 0.0206 \\
At most 2 & 0.385806 & 8.823542 & 15.49471 & 0.3820 \\
At most 3 & 0.002748 & 0.049532 & 3.841466 & 0.8239 \\
\hline
\end{tabular}

Trace test indicates 2 cointegrating eqn(s) at the 0.05 level

* denotes rejection of the hypothesis at the 0.05 level

**MacKinnon-Haug-Michelis (1999) p-values

Unrestricted Cointegration Rank Test (Maximum Eigenvalue)

\begin{tabular}{lllll}
\hline Hypothesized & & Max-Eigen & 0.05 \\
No. of CE(s) & Eigenn value & Statistic & Critical Value & Prob.** \\
\hline None $*$ & 0.951825 & 54.59265 & 27.58434 & 0.0000 \\
At most 1 $*$ & 0.739216 & 24.19313 & 21.13162 & 0.0179 \\
At most 2 & 0.385806 & 8.774010 & 14.26460 & 0.3054 \\
At most 3 & 0.002748 & 0.049532 & 3.841466 & 0.8239 \\
\hline
\end{tabular}

Max-eigenvalue test indicates 2 cointegrating eqn(s) at the 0.05 level

* denotes rejection of the hypothesis at the 0.05 level

**MacKinnon-Haug-Michelis (1999) p-values

Table 2 represents the Mackinon Co-integration Result. The test indicates that there are two Co-integrating equation in the analysis.

From the equation, almost all the independent variables are significant as climatic factors affecting on rice production. Error correction is thus formulated since it has been ascertained that there is a long-run relationship between the variables. 
Table 3 Regression Result for Effect of Climate Change on Rice Production

\begin{tabular}{lllll}
\hline Variable & Coefficient & Standard Error & t-Statistics & Probability \\
\hline HUMIDITY & -17.10789 & 2.722393 & -6.284136 & 0.0000 \\
$\begin{array}{l}\text { MAXIMUM } \\
\text { TEMPERATURE }\end{array}$ & 15.38704 & 10.47694 & & 0.1613 \\
$\begin{array}{l}\text { MINIMUM } \\
\text { TEMPERATURE }\end{array}$ & 52.31507 & 12.59911 & 4.152285 & 0.0007 \\
$\begin{array}{l}\text { RAINFALL } \\
\text { ECM }\end{array}$ & 0.004043 & 0.303408 & 0.013324 & 0.9895 \\
\hline
\end{tabular}

$\begin{array}{llll}\text { R-squared } & 0.922604 & \text { Mean dependent var } & 403.7490 \\ \text { Adjusted R-squared } & 0.903255 & \text { S.D. dependent var } & 132.0721 \\ \text { S.E. of regression } & 41.07961 & \text { Akaike info criterion } & 10.47316 \\ \text { Sum squared resid } & 27000.54 & \text { Schwarz criterion } & 10.72185 \\ \text { Log likelihood } & -104.9682 & \text { Hannan-Quinn criter. } & 10.52713 \\ \text { Durbin-Watson stat } & 1.648469 & & \end{array}$

The estimation result from Table 3 reveals that the explanatory variables jointly account for approximately $92.2 \%$ changes in rice production. The Durbin-Watson statistics illustrate (1.64) absence of auto-correlation. Coincidentally, the goodness of fit for the regression remained low after adjusting for degree of freedom as indicated by the adjusted $\mathrm{R}^{2}\left(\mathrm{R}^{2}=90.3 \%\right)$. The result also shows that humidity and minimum temperature are statistically significant in explaining changes in rice production as a result of climate change. This therefore implies that, $1 \%$ increase in humidity will cause $17.1 \%$ reduction in Rice production in Niger state, this shows a negative impact. Minimum temperature has a positive effect in that for every $1 \%$ increase in minimum temperature there is an increase of $52.3 \%$ in rice production. Rainfall and maximum temperature are not significant in explaining the effect of climate change in rice production in Niger state. This result differs from the result of Ayinde et al., 2011 where rainfall was significant in explaining the effect of climate change on Nigerian agricultural productivity. Insignificance of rainfall on rice production may be linked to the variety of rice that the farmers planted. The use of submergence variety in the study during occurrence of flood will obviously reduce the negative effect rainfall might have on rice production. In line with this, in seasons where temperature is high and rainfall is very low which leads to drought, the use of drought resistant variety in the study will keep the production level in a stage where maximum temperature and reduction in rainfall will not be significant. These justify the essential of innovative variety to coping with climate variability.

\section{Conclusion}

Based on the findings of this research, it can be concluded that there is existence of climate change in Niger state and this is really affecting the agricultural sector of the state. Rice production in Niger state is adversely affected by this climate change as shown by the shock that exist in the production trend. The rice production trend of Niger state is not stable but still one of the best rice output when it reached 600960 tonnes in 1998.

It can also be concluded that the major climatic factors affecting rice production in Niger state is minimum temperature and relative humidity, such that, the higher the relative humidity the lower the rice output from Niger state and the higher the minimum temperature, the higher the rice production.

\section{Recommendations}

Based on the result of this study, the following recommendations are made in order to 
improve the rice production potential of the state and Nigeria at large: Research should be conducted to find means of reducing the effect of climate change which will in turn improve the rice production and agricultural sector of the country. Also, breeders should help to develop rice varieties that can survive higher humidity such that increase in humidity in any environment will not have adverse effect on rice production.

\section{References}

Africa Rice Center (2007), Africa Rice Trends: Overview of Recent Developments in the SubSaharan African Rice Sector. Africa Rice Center Briefs, Africa Rice Center (AfricaRice), Cotonou, Benin, 8pp.

Ayinde, K., Bello, A. A. and Ayinde, O. E (2013), Modelling Nigerian Government Revenues and Total Expenditure: An Error Correction Model Approach. Paper presented at $4^{\text {th }}$ African Association of Agricultural Economists Conference held on September 22$25^{\text {th }} \quad 2013$ at hotel diar lemdina, Hammamet, Tunisia

Ayinde, O. E., Muchie, M. and Olatunji, G. B. (2011), "Effect of Climate Change on Agricultural Productivity in Nigeria: A Cointegration Model Approach" Journal of Human Ecology 189-194 Published by Kamla-Raj Enterprises, India.

Betts, R.A., Fallon, P.D., Goldewijk, K.K and Ramankutty, N. (2007), "Biogeophysical Effects of Land Use on Climate: Model Simulations of Radiactive Forcing and Large-Scale Temperature Change" Agricultural and Forest Meteorology, 142, 216-233.

Botkin, D. B. and Keller, E. A. (2000), Environmental Science: Earth as a Living Planet. Danvers, MA.: John Wiley \& Sons, Inc

Boucher, O., Myhre, G. and Myhre, A. (2004), "Direct Human Influence of Irrigation on Atmospheric Water Vapour and Climate" Climate Dynamics, 22, 597-603.

Consultative Group on International Agricultural Research, CGIAR (2009), Climate, Agriculture and Food Security: a Strategy for Change. http//: www.cgiar.org accessed on April, 2013.
Dickey, D.A. and Fuller, W.A. (1981), Likelihood ratios statistics for autoregressive time series with a unit root. Econometrica, 49(4), 1057-1072

Engle, R. F. and Granger, C.W. T. (1987), Cointegration and Error Correction Representation, Estimation and Testing. Econometrica, 55, 215276.

Futakuchi, K. (2005), "Submergence Damage in Rice and Challenges in Expanding the Crop's Adaptability to Submerged Conditions in West and Central Africa" In: Toriyama K, Heong

Palada, M. C. and Vergara, B. S., 1972. "Environmental Effects on the Resistance of Rice Seedlings to Complete Submergence" Crop Science, 12, 209-212.

Goodwin, B.K. and Schroeder, T.C. (1991), Cointegration Test and Spatial Price Linkages in Regional Cattle Markets. American Journal of Agricultural Economics, 73(2), 452- 464.

Inter-governmental Panel on Climate Change, IPCC (2002), Group II working Report on Climatic Variability. Contribution of working Group II to the Third Assessment of the Intergovernmental Panel on Climate Change. Inter-govenmental Panel on Climate Change, IPCC (2007): Fourth Asssessment Report of the Intergovernmental Panel on Climate Change: The Impacts, adaptation and vulnerability (Working Group III). Cambridge University Press, United Kingdom and New York, NY, USA

Johansen, S. (1992), 'Determination of Cointegration Rank in the Presence of a Linear Trend'. Oxford Bulleting of Economics and Statistics, 54, 383-97.

Johansen, S. and Juselius, K. (1990). 'Maximum Likelihood Estimation and inference on cointegration - With Application to the Demand for Money', Oxford Bulletin of Economics and Statistics, 52, 169-210

Khanal, R.C. (2009), "Climate Change and Organic Agriculture" The Journal of Agriculture and Environment, 10,100-110.

MacKinnon, J. G., Haug, A. A and Michelis, L. (1999), "Numerical Distribution Function of Likelihood Ratio Tests for Cointegration" Journal of Applied Econometrics, 14(5), 563-77 
Matthews, R.B., Kropff, M.J. Horie, T. and Bachelet, D. (1997), "Simulating the Impact of Climate Change on Rice Production in Asia and Evaluating Options for Adoption. Agricultural Systems, 54,399-425.

Lal, R., Kimble, J.M., Follet, R.F. and Cole, C.V. (1998), The Potential of U.S. Cropland to Sequester Carbon and Mitigate the Greenhouse Effect. Boca Raton: CRC Press.

Odjugo, P.A.O. (2010), "General Overview of Climate Change Impacts in Nigeria" Journal Hum. Ecol., 29(1), 47-55.

Olaniyan, O.J. (1981), "Research in Agroclimatology in Nigeria". Journal of Agric. Research 9,15-29.

Ozor, N. (2009), Implications of Climate Change for National Development - The Way Forward, in Enugu Forum Policy Paper 10, Enugu, African Institute for Applied Economics.
Schneider, S.H. (1989), Global Warming: Are We Entering the Greenhouse Century? San Francisco: Sierra Club Books

Smith, P., Martino, D., Cai, Z., Gwary, D., Jansen, H. Kumar, P. McCarl, B. Ogle, S., Wattenbach, M. and Smith, J. (2008), "Greenhouse Gas Mitigation in Agriculture" Philosophical Transactions of the Royal Society, 363,789-813

Verge, X.P.C., Dyer, J.A., Desjardins, R.L. and Worth, D. (2009), "Greenhouse Gas Emissions from the Canadian Pork Industry" Livestock Science 121, 92-101.

Wassmann, R., Butterbach-Bahl, K. and Dobermann, A. (2007), "Irrigated Rice Production Systems and Greenhouse Gas Emissions: Crop and Residue Management Trends, Climate Change impacts and mitigation strategies" CAB Reviews: Perspectives in Agriculture, Veterinary Science, Nutrition and Natural Resources, 2, 4-14. 